\title{
MARKETING STRATEGY ANALYSIS OF NANO TEA PRODUCT BASED ON MANGOSTEEN PEEL (GRACINIA MANGOSTANA) TO PROMOTE FUNCTIONAL FOODS INDUSTRY
}

\author{
Syukri Yusuf Nasution ${ }^{* 1}$, Gita Andini**), Yoga Prawira**), and Dhini Azzahra**) \\ ${ }^{*}$ Research Center for Policy and Science, Technology and Innovation Management - LIPI \\ J1. Gatot Subroto 10, Jakarta 12710 \\ ${ }^{* *}$ Center for Innovation - LIPI \\ J1. Raya Jakarta Bogor KM 47, Cibinong 16912
}

\begin{abstract}
A marketing strategy analysis is an overview of the potential that can be generated from marketing aspects. This analysis is conducted to overview the feasibility of the product if it entered the market. In this research, the marketing strategy analysis uses three methods: (1) Business Model Canvas (BMC) analysis as a business model of the product; (2) Competitor Intelligence (CI) analysis to observe the product's position to be developed, compared to the existing products in the market; and (3) Marketing Element analysis to analyze the potential market of the product which can be observed from segmentation, market size potential market, and also the size of the market share of the product. This study uses qualitative and quantitative methods by collecting both secondary and primary data. In the Business Model Canvas (BMC) analysis shows the nano tea product based on mangosteen peel has two business models that are being recommended for the marketing strategy, those are Business to Business (B2B) and Business to Customer (B2C) models. In the Competitor Intelligence $(\mathrm{CI})$ analysis, shows that the product has two success factors to increase the competitive value of the product i.e. success factors in the form of tea powder and nano-size. Those factors will make the product has better efficacy and functions compared to similar tea in other form. While the results of marketing elements analysis of the product will be focused on West Java market, with the value of market share of $0.05 \%$ or about 35,904 ton/years from the total market of 72,903.6 tons/years.
\end{abstract}

Keywords: market strategy, competitor intelligence, business model canvas, marketing analysis

\begin{abstract}
Abstrak: Analisis strategi pemasaran adalah gambaran umum tentang potensi yang dapat dihasilkan dari aspek pemasaran. Analisis ini dilakukan untuk meninjau kelayakan produk jika memasuki pasar. Dalam penelitian ini, analisis strategi pemasaran menggunakan tiga metode: (1) Analisis Business Model Canvas (BMC) sebagai model bisnis produk; (2) Analisis Competitor Intelligence (CI) untuk mengamati posisi produk yang akan dikembangkan dibandingkan dengan produk yang ada di pasar; dan (3) Analisis Elemen Pemasaran untuk menganalisis potensi pasar dari produk yang dapat diamati dari aspek segmentasi, besaran pasar potensi pasar, dan juga ukuran pangsa pasar produk. Penelitian ini menggunakan metode kualitatif dan kuantitatif dengan mengumpulkan data sekunder dan primer. Dalam analisis Business Model Canvas (BMC) menunjukkan produk teh nano kulit manggis memiliki dua model bisnis yang direkomendasikan untuk strategi pemasaran, yaitu model Business to Business (B2B) dan Business to Customer (B2C). Dalam analisis Competitor Intelligence (CI) menunjukkan bahwa produk tersebut memiliki dua faktor keberhasilan untuk meningkatkan nilai kompetitif produk, yaitu faktor keberhasilan dalam bentuk the bubuk dan berukuran nano. Dengan faktor-faktor tersebut akan membuat produk memiliki khasiat dan fungsi yang lebih baik dibandingkan dengan teh sejenis. Sedangkan hasil analisa pasar menunjukkan elemen pemasaran produk teh kulit nano manggis akan difokuskan di pasar Jawa Barat, dengan nilai pangsa pasar 0,05\% atau sekitar 35.904 ton / tahun dari total pasar 72.903,6 ton / tahun di Jawa Barat.
\end{abstract}

Kata kunci: strategi pasar, intelegensi pesaing, kanvas bisnis model, analisa pasar

\footnotetext{
${ }^{1}$ Corresponding author:

Email: syukri.pusinov.lipi@gmail.com
} 


\section{INTRODUCTION}

Indonesia is a country with a huge potential in the field of horticulture. Fruits are one of the agricultural sub-sectors that has seen an increase in production. One fruit that have been cultivated for a long time by Indonesians is mangosteen. Mangosteen commodity in Indonesia has the second highest growth rate after mangoes: 84,538 tons in 2010; 117,595 tons in 2011; 190,287 tons in $2012 ; 139,602$ tons in $2013 ; 113,096$ tons in 2014; and 144,957 tons in $2015 ; 162,864$ tons in 2016; and 161,758 tons in 2017 (BPS, 2017) .

Mangosteen peel, previously considered as a waste, but now, mangosteen peel known has a benefit. Mangosteen contains active substances such as xanthones, anthocyanins, tannins, and other phenolic compounds (Ningsih, 2017). Furthermore, the mangosteen peel capable to preventing degenerative diseases such as coronary heart disease, cancer, diabetes, hypertension, stroke, and Alzheimer's disease (Lako, 2007)

When the mangosteen peel contains xanthones, there are several functions of the xanthones, this xanthones can be used as "added value" if the mangosteen peel processed into nano tea. The function of the xanthones are: (i) as anti-inflammatory, (ii) as anti-bacterial, (iii) as anti-diabetes, (iv) as anti-fungal, (v) as anti-virus, and (vi) as anti-oxidant (Putra, 2011). Mangosteen peel also known has a good antioxidant which can treats a cell damage and inhibit the aging process (Palakawong, 2010).

Today, mangosteen peel has processed into several products including tablets, syrup, tea, natural dyes, and other functional foods. More specifically, the processing of mangosteen peel into nano tea is also developing by Indonesian Institute of Sciences (LIPI), where the development of nano-based technology expected to provide greater value compared to standard extraction formulation technology. The nano technology process is also expecting to have a significant impact on the economic value of the product. New Product Development based on mangosteen peel especially to make a nano tea based on mangosteen peel is a new one in Indonesia. Until now, there is no product of nano tea based on mangosteen peel has existed in the market. Therefore, in this research, focused on to define the market opportunity of the product if the product launched into the market. Besides that, this research try to formulate how the strategy should be taken to make this product compete with the similar product in the market.

Therefore, to looking the possibility of business potential of the product, a more in depth analysis needed. In this research, to look this potential market using Business Model Canvas (BMC) analysis, Competitor Intelligence (CI) analysis, and the analysis of potential marketing capabilities, to shows the potential of the product to compete with similar products in the market. The results of this activity expected can make a consideration and recommendation process in the business development of a highly competitive of nano mangosteen peel tea product against other tea products in the market. Besides that, these results also expected can used to find networks and commercial deals with partners for the commercialization this product in Indonesia.

\section{METHODS}

In this research conducted quantitative - qualitative methods by descriptive analysis (Creswell, 2003). Quantitative research is a research by obtaining data in the form of numbers or qualitative data that are quantified. While qualitative research uses qualitative data that can be described in the form of words, flowcharts figures. Furthermore, descriptive research is used to determine the value of independent variables by making comparisons or not making comparisons with other variables (Sugiyono, 2013).

This research also conducted by using primary and secondary data. The primary data obtained from Research Center of Physic LIPI as technology manufacturer (inventor), PT. Nano Herbal Indonesia as trial production of product nano tea based on mangosteen peel; PT Sinar Sosro and CV. Putra Farma Yogyakarta (in order to find the analysis strategy marketing of the product); and farmers and mangosteen plantation managers in West Sumatra and Central Java (under the guidance of Horticulture and Plantation Services in the District of Lima Puluh, West Sumatra and Central Java Province Plantation Office) to find out the supply chain of the raw material for the nano tea based on mangosteen peel. The secondary data obtained from study literature and desk study. This research conducted in 1 year in 2018. 
The design of the business model is a form of marketing strategy, which determined through the Business Model Canvas (BMC) analysis. Business Model Canvas (BMC) is a business model that representing a logical framework on how an organization creates, delivers, and captures a value. This Business Model Canvas separate into 9 main blocks, which are divided into the right (creative side) and left (logical side) components: just like the human brain. The nine components are as follows: Customer Segment, Customer Relationship, Customer Channel, Revenue Stream, Value Proposition, Key Activities, Key Resources, Cost Structure, and Key Partners (Osterwalder, 2010).

One of market strategy for products to become more popular and accepted is through competitive intelligence analysis or CI analysis (Xia and Gong, 2012). The CI analysis can provide a visualization of the product's position compared to its counterparts. The development of CI analysis is an important process for each business for several reasons: by gathering information about competitors it can analyse the skills and competencies our products have, improve their capabilities, and predict future competitors' behaviour and actions in order to maintain or improve their market position. More importantly, CI creates comparative knowledge that enables companies to highlight their strengths, and to improve the weaknesses through product differentiation and/or services offered in the market (Cobb, 2003). In this analysis uses success factors as independent variables, and compare it with similar products to the nano tea based on mangosteen peel. In literature. The definition of a success factor is "conditions, characteristics, or variables that properly sustained, maintained, or managed, which have a significant impact on the success of product to gain an revenue and to competing in particular business" (Leidcker, 1984).

Marketing strategy plan is a series of steps where one can find a number of activities that are all tied together (Middleton, 2013). The process of the marketing strategy begins by analysing the current market conditions about the product and the competitors. Market condition analysis has correlation in which the entrepreneurs often to try to identify the success key factors, such as demand, growth potential and market attractiveness. To identify these factors, the key success factor must be has a specific value, measurable, achievable, and has an impact in a several time.

In other word, the marketing plan must begin with a clear understanding of the customer's needs or problems and how the product or service will satisfy these needs (value proposition). Furthermore, in terms of marketing, the company must at least know the basic concept in the field of marketing itself, where some literature say that this basic concept comes from practical marketing science that can be applied directly in business activities (Kartajaya, 2007).

The analysis of marketing strategies is focused on 3 main analyses. First, the Business Model Canvas analysis is carried out as a recommended business model for nano mangosteen peel tea product. The next step is to analyze the position of the nano mangosteen peel tea product compared to similar products by using the Competitor Intelligence (CI) analysis. The CI analysis is focused on the analysis of the success factors possessed by each product. In CI method, in-depth analysis conducted to obtain the new success factors that can be used as competitive factors of the nano tea product based on mangosteen peel to compete with the competitors in the market. On in-depth analysis, some success factors are determined through interviews with PT. Nano Herbal Indonesia, PT. Sinar Sosro, and CV. Putra Farma Yogyakarta to defines the probability of new values of the product. These new values are expected to make the product has a differentiation with other products.

And the last is by using the market element analysis, which will define the value of the segmentation, market size and also the value of market share of the mangosteen peel nano tea product in the market. Market segmentation is the process of dividing up mass markets into groups with similar needs and wants. Segmentation can be defined based on Demography, Geographic, Psychographic, and Behavioural segmentation (Pride, 2018). Market size is the number of individuals in a certain market who are potential buyers and/or sellers of a product. And the market share is the percentage of a market accounted for by a specific entity (Farris et al. 2010). Research framework shown in Figure 2. 

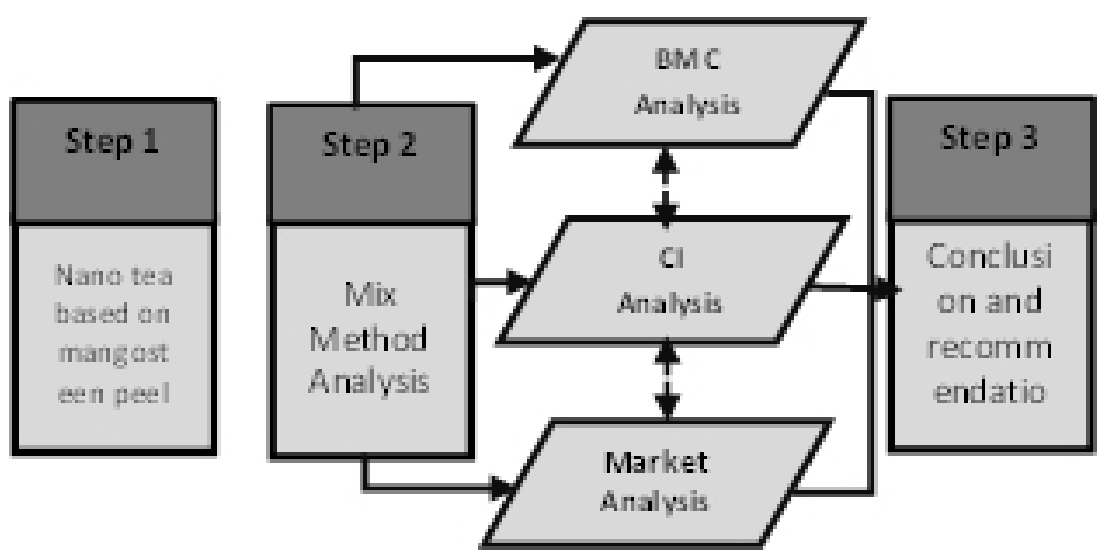

\section{RESULTS}

\section{Business Model Canvas Analysis}

Based on interviews with PT. Nano Herbal Indonesia, an overview of the nano mangosteen peel tea product Business Model Canvas can be obtained by describing each block of variables contained in the Business Model Canvas, while the nine elements contained in the Business Model Canvas are outlined in the Figure 2.

Based on the Figure 2, the customer segments for mangosteen peel nano tea are people ages 20-60. This customer segment are grouped based on analysis from interview with PT. Nano Herbal Indonesia, PT. Sinar Sosro and CV. Putra Farma Yogyakarta. Based on the interview, it can be inferred that the best average age to use the product is about $20-60$ years old.

The value proposition of nano mangosteen peel nano tea is its process of the production of the product. In production process use nanotechnology. With this form (nano-size) will has the efficacy to nourish the body effectively than others form. In the channels section, the channelling of mangosteen peel nano tea is has three ways. First is offline ways, where customers can be served face to face. Second is online through Instagram features and market place websites. And the third ways is resellers of mangosteen peel nano tea. Customer relationships of the product are done through customer service and discount. For customer service, the customers can voice their complaints and suggestions by telephone, e-mail, and social media platforms. While discounts prices are given to attract customer to buy the product.
Revenue streams from mangosteen peel nano tea can be obtained from various methods. First is direct sales to customers, which the product directly received by the customers from main provider (without intermediaries). In this method usually called as Business to Customers (B2C) type. The second is the profit sharing can be obtained by generated from products distributed through pharmacies, herbal shops, food stores/convenience stores, and others. Usually this method is conducted with third parties as sellers. The last method to gain revenue by this product is by licensing and royalties agreement on the technology. Which in this method, the licensee (the recipient of license and royalty), has an authority to produce the product of mangosteen peel nano tea by using the technology in within certain period based on agreement. The second and the third methods usually called as Business to Business (B2B) type. Which the revenue can be gained from the agreement with the third parties and the profit obtained indirectly from sales of the product.

From Figure. 2 also describes the key resources of this product are human resources consisting of managers, operational officers, marketers, and nano engineering experts. In addition, physical assets in the form of production buildings, production equipment (nano machines and blending machines), and investors are also become as key resources of the business model of mangosteen peel nano tea. For the key activities of the nano tea product based on mangosteen peel are focus on production (enumeration, drying, blending and nanofabrication); promotion/marketing; and sales of the product. Key partners are main partner on developing the business of mangosteen peel nano tea such as mangosteen fruit farmers, laboratory testing services for product testing, packaging suppliers, and licensing (permit) agencies such as National Agency of Drug and Food Control of Republic of Indonesia (BPOM) 


\begin{tabular}{|c|c|c|c|c|c|}
\hline Key Partner & Key Activities & \multicolumn{2}{|c|}{ Value Proposition } & Customer Relationship & Customer Segment \\
\hline \multirow[t]{3}{*}{$\begin{array}{l}\text { - } \text { Supplier of raw } \\
\text { materials: mangosteen } \\
\text { farmers } \\
\text { - Lab test services } \\
\text { - Packaging suppliers } \\
\text { - } \text { BPOM } \\
\text { - MUI (Indonesia } \\
\text { Ulema Council) }\end{array}$} & $\begin{array}{l}\text { - Production process } \\
\text { (enumeration, } \\
\text { drying, blending and } \\
\text { nanofabrication) } \\
\text { - Promotion/marketing } \\
\text { activities } \\
\text { - Sales }\end{array}$ & \multirow{3}{*}{\multicolumn{2}{|c|}{$\begin{array}{l}\text { - Using nanotechnology } \\
\text { - The benefits of the } \\
\text { nano mangosteen peel } \\
\text { tea product to nourish } \\
\text { the body } \\
\text { - Nano powder (form) }\end{array}$}} & $\begin{array}{l}\text { - Customer Service } \\
\text { - Discount }\end{array}$ & \multirow[t]{3}{*}{ - People ages $20-60$} \\
\hline & Key Resources & & & Channel & \\
\hline & $\begin{array}{l}\text { - Managers, } \\
\text { Operational, } \\
\text { Marketing Division } \\
\text { - Nanotechnology } \\
\text { experts } \\
\text { - Production buildings } \\
\text { - Production equipment } \\
\text { (Nano machinery and } \\
\text { blending machine) } \\
\text { - Investors }\end{array}$ & & & $\begin{array}{l}\text { - Offline : Direct sales } \\
\text { (directly) } \\
\text { - Online : marketplace } \\
\text { websites } \\
\text { - Reseller }\end{array}$ & \\
\hline \multicolumn{3}{|l|}{ Cost Structure } & \multicolumn{3}{|c|}{ Revenue Streams } \\
\hline \multicolumn{3}{|c|}{$\begin{array}{l}\text { - Fixed cost (Production equipment purchase and building leases } \\
\text { for production) } \\
\text { - Variable cost (payroll expenses, promotion costs, raw material } \\
\text { purchases, electricity expense, etc.) } \\
\text { - Promotion cost }\end{array}$} & \multicolumn{3}{|c|}{$\begin{array}{l}\text { - Direct sales to customers } \\
\text { - Profit sharing from products distributed to pharmacies, herbal } \\
\text { shops, food stores / convenience stores } \\
\text { - Licensing } \\
\text { - Royalties }\end{array}$} \\
\hline
\end{tabular}

Figure 2. Business Model Canvas (BMC) of mangosteen peel nano tea

and Indonesian Ulema Council (MUI). Furthermore, from the cost structure in BMC analysis describes the expenditure costs which incurred in production activities. There are two types of the expenditure cost in this model business namely fixed costs and variable costs. In fixed cost, there are several expenditures which are used to purchase routine expenses such as to purchase of production equipment, and also to purchase the rent of building production. While the variable cost are used to purchase the expenditures that can be changes over period of time. This kinds of cost are payroll expenses, promotion costs, raw material purchases, electricity expenses, promotion, etc.

From the analysis of Business Model Canvas (BMC), two business models are being recommended for the marketing strategy of mangosteen peel nano tea, namely Business to Business (B2B) and Business to Customer (B2C). B2B model can be conducted by licensing and royalty agreement. For B2B model, it will focus on using the technology to produce mangosteen peel nano tea, which is namely nanofication technology. Since nanotechnology is new in Indonesia, LIPI has the opportunity to establish cooperation through licensing or royalties in nanotechnology with other companies engaged in the fields of technology and business. While the B2C model business can be conducted by sale the product directly to the customers or user. B2C business model focuses on the price of the product to gain the profit. Which the price must be analysed based on feasibility investment to obtain the reasonable price compared with the price the competitors.

\section{Analysis}

"Success factors" are important components that must be defined in CI analysis, because it will be used to mapping the position of the nano tea product based on mangosteen peel with the similar products in the market. In Figure 3 shows the process of the CI analysis of the product (Rifai, 2011).

In the CI analysis of product of mangosteen peel nano tea, discussed with PT. Nano Herbal Indonesia PT. Sinar Sosro, and CV. Putra Farma Yogyakarta, there are five success factors defined and analysed: Taste (as a success factor 1); Flavour (as a success factor 2); Price (as a success factor 3); Concentrate (as a success factor 4); Health functions (as a success factor 5). 


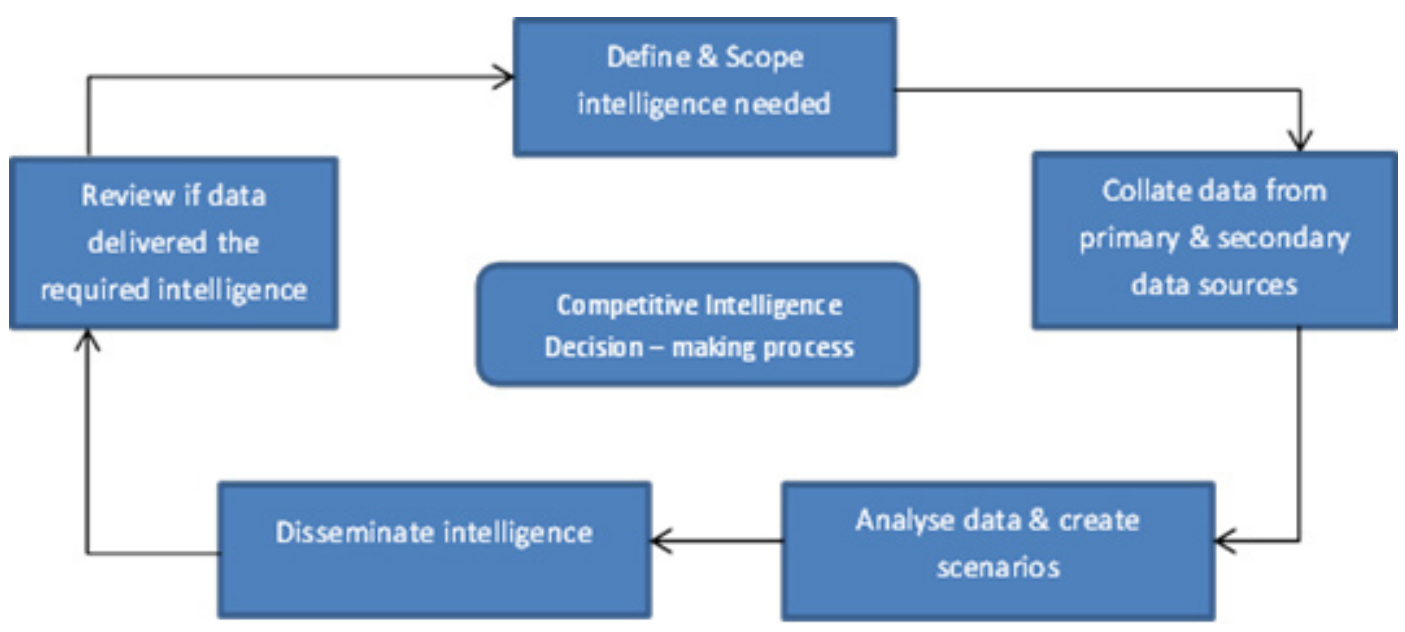

Figure 3. Competitive intelligence process (Rifai, 2011)

These success factors are obtained from primary and secondary data. Primary data is obtained directly from interviewees: PT. Nano Herbal Indonesia, PT. Sinar Sosro, and CV. Putra Farma Yogyakarta; while secondary data is obtained through desk studies related to the product.

In the CI analysis process, the first thing to do is to describe the predetermined success factors. There are several prerequisites used to determine a success factor, (Rifai, 2011): the explanation must be easy to understand, if the data showed in table or graphic, the meaning of the data or graphic can be easy to understand; the explanation must be measurable; the explanation shall use specific vulnerable values so that they are measured properly; the explanation is certain and does not create confusion; The explanation must certainly use an objective approach.

In this analysis, the 5 success factors above are mapped by using a scoring value. The scoring used to describe the level of the success factors of the product compare with the similar products in the market. The scoring value uses from 1 to 5 degree. The lowest value means that the success factors of the product has a low value compared with the competitors, and the highest value means the success factors of the product has the best value compare with the competitors. The CI analysis for these success factors shown in Tables 1.

The success factors above compared with 5 competitors. These competitors have a similar product with the mangosteen peel nano tea. Based on the analysis, the positioning of the mangosteen peel nano tea compared with the 5 competitors shown in Figure 4.
Table 1. Success factor $1-5$

\begin{tabular}{ll}
\hline Criteria & Value level \\
\hline Success factor 1 (Taste) & \\
Sour and bitter & 1 \\
Quite sour and bitter & 2 \\
Quite sour and quite bitter & 3 \\
Quite sour and not bitter & 4 \\
Not sour and not bitter & 5 \\
Success factor 2 (Flavour) & \\
Not sweet smelled/smelly & 1 \\
Less smelly & 2 \\
Quite sweet-smelling & 3 \\
Fairly sweet-smelling & 4 \\
Sweet-smelling & 5 \\
Success factor 3 (Price) & \\
Rp. 30,000 - Rp. 35,000 & 1 \\
Rp. 25,000 - Rp. 30,000 & 2 \\
Rp. 20,000 - Rp. 25,000 & 3 \\
Rp. 15,000 - Rp. 20,000 & 4 \\
Rp. 10,000 - Rp. 15,000 & \\
Success factor 4 (Concentrate) & 5 \\
Not concentrated & \\
Less concentrated & \\
Quite concentrated & \\
Fairly concentrated & \\
Highly concentrated & 2 \\
Success factor 5 (Health function) & \\
Refreshing the body & \\
Refreshing the body, increases stamina & \\
Make the body healthier, increases stamina & 3 \\
Refreshing the body, make your body & 4 \\
healthier & \\
Refreshing the body, make the body & \\
healthier, increases stamina & \\
\hline & \\
& \\
\hline
\end{tabular}


From Figure 4, shows that mangosteen peel nano tea product has no a significant value compared with the competitors. It is means that the product of mangosteen peel nano tea does not has a value added if delivered to the market. It will make the product of the mangosteen peel nano tea will be difficult to be survive in the market. The positioning of the product of mangosteen peel nano tea is shown in diagram Figure 5.

Based on the Figure 5, it describes the positioning of product of mangosteen peel nano tea is in quadrant III "unknown (listening" position. It means that the product of mangosteen peel nano tea has no competitiveness compared with the competitors. This position will make the stakeholder and investors will not give and opportunity to develop the product in the business. To make the product can be move from quadrant III to quadrant I, it must be sought the new success factors that are not owned by the competitors. To define the new success factors in-depth analysis conducted by analysing the same types of the product but is not a competitors for mangosteen peel nano tea product. From this in-depth analysis obtained 2 success factors to enhance the competitiveness of mangosteen peel nano tea product. By using the success factors on Table 2 and Table 3 show the positioning of nano tea product based on mangosteen peel compared with the competitors shown in Figure 6.
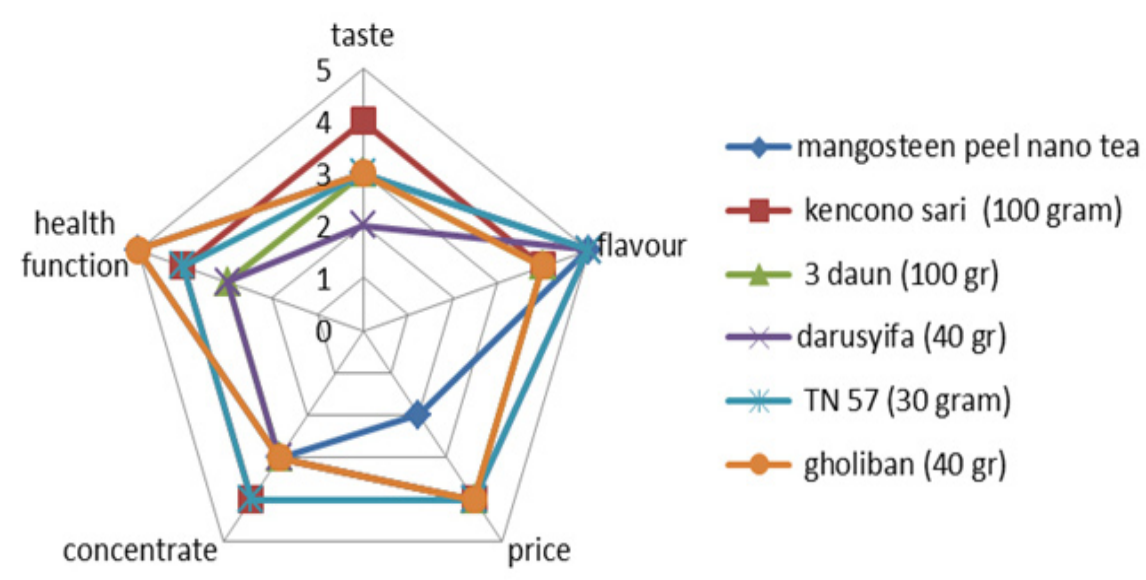

Figure 4. Mapping of nano mangosteen peel tea product position compared with similar products (competitors)

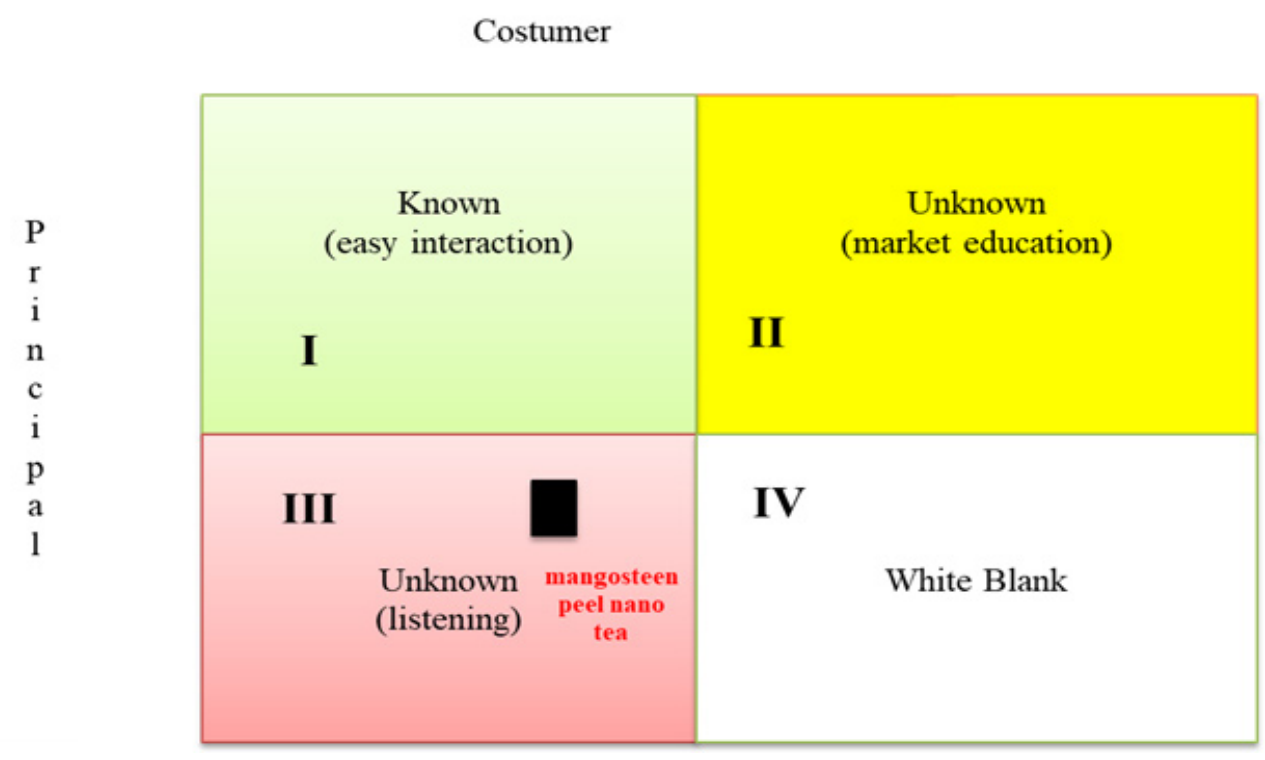

Figure 5. Positioning of nano tea product based on mangosteen peel in the market based on success 
Success factors that shown in Figure 6 are the new success factors as value added for product of mangosteen peel nano tea. Which this value added is not owned by the other competitors. Product of mangosteen peel nano tea has a unique process production. The process production is using nanotechnology as a core technology to produce the product. This method is the new competitiveness for the product of mangosteen peel nano tea because the other products have no nanofication in the process production. Because the product of mangosteen peels nano tea using nano technology, so the result of the product also has a unique form compared with the others. With the nanopowder form, the efficacy of the function of the tea more absorbable than usual (dip powder). With these success factors expected the product of mangosteen peel nano tea can compete in the market. The positioning after adding these success factors as value added of the nano tea product based on mangosteen peel shown in Figure 7. From Figure 7 show the product has a chance to move from quadrant III to quadrant I. this displacement is due to the new value of nano tea product based on mangosteen peel which used as a new competitiveness to make the product survive in the market.

\section{Marketing Potential Analysis}

Any product, brand or company will have a good competitive advantage if the company is capable of developing the concept of nine marketing elements. The nine marketing elements can be described through the following STVs (Kartajaya, 2005):

From these 9 marketing elements, the development of the marketing strategy for the mangosteen peel nano tea product will be focused on several basic elements. Those marketing elements are segmentation, targeting (including market size and market share analysis), differentiation, and the value of mangosteen peel nano tea product.

\section{Segmentation}

The mangosteen peel nano tea product is segmented for all consumers in West Java with ages 20 to 60. This product is intended for consumers who have an interest in herbal products with certain benefits.

\section{Market Size}

Market size is needed to find out the projected demand of similar products, so that conclusions can be drawn on how much consumers demand the mangosteen peel nano tea product. Empirically, the size of the tea market in Indonesia is shown in Table 3 (Directorate General of Plantation, production tea in Indonesia, 2017).

From Table 3 show that tea production in Indonesia reaches an average of 156,206 tons per year, and $92.74 \%$ or 144,875 tons of tea is consumed by people of Indonesia. While tea consumption data in Indonesia is shown in Table 4.

Table 2. New success factor (1-2)

\begin{tabular}{lc}
\hline Criteria & Value level \\
\hline Success factor 6 (Production method) & \\
Non nanofabrication & 1 \\
Non-high energy mill nanofabrication & 2 \\
Nanofabrication with high energy mill & 3 \\
Non-planetary ball mill nanofabrication & 4 \\
Nanofabrication with planetary ball mill & 5 \\
Success factor 7 (Product form ) & \\
Thin liquid & 1 \\
Thick liquid & 2 \\
Rough powder & 3 \\
Fine powder & 4 \\
Nano powder & 5 \\
\hline
\end{tabular}

Table 3, Tea production in Indonesia

\begin{tabular}{lrrrrrr}
\hline \multirow{2}{*}{ Province } & \multicolumn{7}{c}{ Production (tons) } \\
\cline { 2 - 7 } & \multicolumn{1}{c}{2012} & \multicolumn{1}{c}{2013} & \multicolumn{1}{c}{ (2014 } & \multicolumn{1}{c}{.15 } & \multicolumn{1}{c}{2016} & Average \\
\hline West Java & 102,722 & 102,956 & 105,279 & 105,141 & 104,148 & 104,148 \\
North Sumatera & 13,264 & 13,159 & 12,819 & 13,121 & 13,122 & 13,122 \\
Central Java & 9,680 & 9,542 & 11,505 & 11,524 & 10,759 & 10,759 \\
West Sumatera & 7,619 & 7,713 & 7,999 & 8,013 & 7,899 & 7,899 \\
Jambi & 5,269 & 5,265 & 5,265 & 5,268 & 5,268 & 5,268 \\
Other & 12,290 & 12,090 & 12,090 & 16,799 & 15,010 & 15,010 \\
Nationwide & 145,575 & 145,460 & 154,369 & 154,598 & 154,688 & 156,206 \\
\hline \hline
\end{tabular}




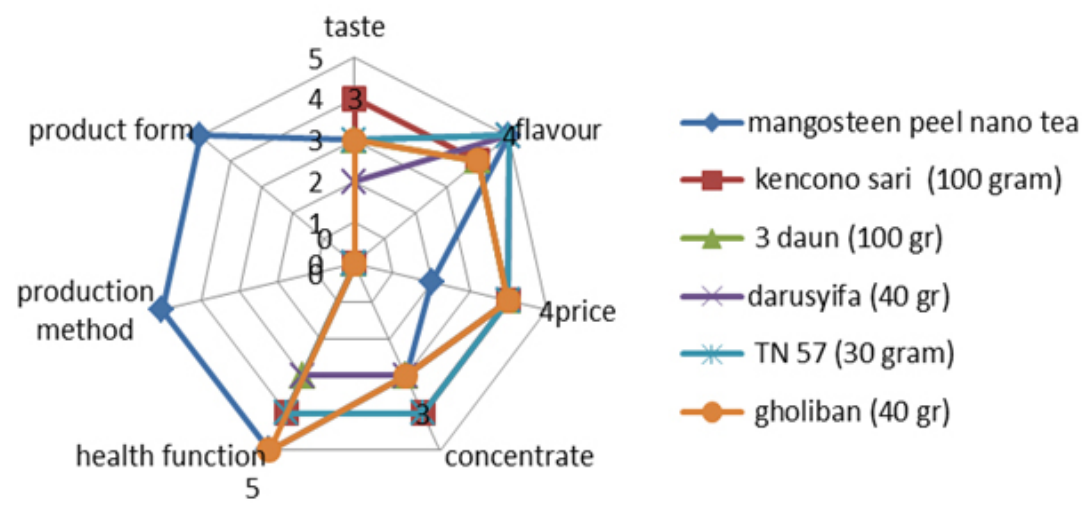

Figure. 6 Mapping of mangosteen peel nano tea product after adding new success factors

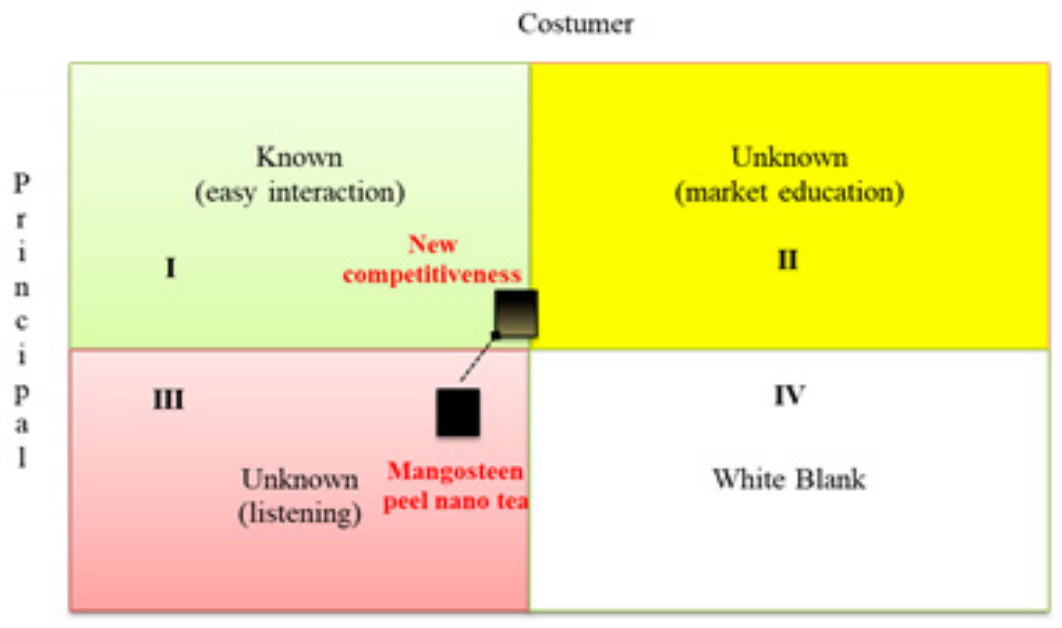

Figure. 7 Positioning product of mangosteen peel nano tea with new competitiveness

Table 4. Tea consumption data in Indonesia:

\begin{tabular}{cccc}
\hline Year & Consumption $(\mathrm{Kg} /$ Capita/Year) & Population (000 People) & National Consumption (Tons) \\
\hline 2015 & 0.57 & 255,462 & 154,613 \\
2016 & 0.56 & 258,705 & 144,875 \\
2017 & 0.54 & 261,891 & 141,421 \\
2018 & 0.52 & 265,015 & 137,808 \\
2019 & 0.51 & 267,974 & 136,667 \\
Average growth (\%/Year) & -2.74 & 1.20 & -1.57 \\
\hline
\end{tabular}

From the data above, the projected tea consumption in 2016 is 144,875 tons and it will be increasing in the following years. This shows a huge opportunity for market penetration of mangosteen peel nano tea to fulfil the demand of tea especially in Indonesia.

\section{Potential Market}

In this study, the markets that will be targeted is West Java, with an amount of $46,497,175$ people. West Java become a target market of the product because in this area has a huge potential of mangosteen fruit, amounting to 7.8 tons/years. In addition, West Java is the province with the largest tea production in Indonesia. The amount of tea production in West Java reaches 104.148 tons in 2016. If assumed that the level of tea production to be consumed by consumers is $70 \%$ or about $72,903.6$ tons, it is still a huge number for product of mangosteen peel nano tea to fulfil that demand. 


\section{Market Share}

From the market potential available in West Java, amounting to 72,903.6 tons for all types of tea, the mangosteen peel nano tea product will target the herbal tea consumer market. The projected productivity of mangosteen peel nano tea product is $35,904 \mathrm{Kg}$ per year, or about $300 \mathrm{~kg} / \mathrm{day}$ and the selling price is $\mathrm{Rp} 55,000 / \mathrm{Kg}$ or about Rp 11,000/200 gram. By the data, the market share of the mangosteen peel nano tea to fulfil the demand on west java is about $0.05 \%$ or amount $35,904 \mathrm{Kg}$ a year.

\section{Differentiation}

The processing of mangosteen peel has been widely developed, such as in the products of syrup, tea, natural dyes and other functional food ingredients. As for the development of tea products, there are also several tea products based on mangosteen peel. However, existing mangosteen peel tea products are still being developed only with standard extraction technology.

Mangosteen peel nano tea product uses nanotechnology which is a differentiating value when compared with other products. By nanotechnology can provide more significant added value compared to standard extraction formulation technology. In addition, the mangosteen peel nano tea product are available in nano size form, which is contrast with similar products in the market. The development of tea in nano powder product will be an alternative for consumers to try the tea with a "unique form". Besides that, with the nano size form, it will increase the efficacy of the tea for body health.

\section{Value}

The mangosteen peel nano tea product is a product created based on technology. With this condition will make the brand of the product more effectively, because the product has a scientific result to strengthen the functional of the mangosteen peel nano tea product. With this value, expected can be educate the consumers about alternative products with a high antioxidants value.

Furthermore, mangosteen peel has many benefits because it contains active substances such as xanthone, anthocyanins, tannins, and other 3 phenolic compounds. Mangosteen peel is also deemed capable of preventing degenerative diseases such as coronary heart disease, cancer, diabetes, hypertension, stroke and Alzheimer's disease. In addition, mangosteen peel can also act as an antioxidant, anticancer, anti-inflammatory, antibacterial, antifungal, and others. The ingredient of mangosteen peel is shown in Table 5. Further, the mangosteen peel nano tea product is produced by using nanotechnology. All product with a nano size, it means that this product can be easily absorbed in human body.

Table 5. Mangosteen peel nutrition content

\begin{tabular}{lc}
\hline Components & \% Dry Matter \\
\hline Protein Concentration & Low \\
Crude Fiber & 29.4 \\
Starch & - \\
Tannin Concentration & 1.1 \\
Concentration of substance soluble in & 4.5 \\
isohexane & \\
Percentage of Ash & 4.5 \\
\hline
\end{tabular}

Source: Nurkamari (1979)

\section{Managerial Implications}

New Product Development has many implications to creating and establish strategy market. Some of them is can be used to generate and establish of new startup company based on technology competitiveness. In this research, the start-up can be define how to creating and establish new product to compete with the others by using the analytical of market strategy. Besides that, developing new product based on technology has an implication to build the new ecosystem to fulfil the link between the capacity and capability of the start-up to provide product availability and linking between the consumers needed. More implication of this research also to make a decision and strategy for the owner of technology to define how to commercialize the technology needed in order to developing new product (in this case is nano tea based on mangosteen peel).

\section{CONCLUSIONS AND RECOMMENDATIONS}

\section{Conclusions}

Marketing strategy analysis is conducted to avoid product failure when it's delivered to the market. Therefore, it is expected that the marketing strategy analysis can form a strong foundation for developing a new product to be able to compete in the market. In this research, marketing strategy analysis is conducted for nano tea product based on mangosteen peel, which is a 
new product development that will be introduced to the market. From this research, three method of marketing strategy conducted to obtain the best strategy marketing for mangosteen peel nano tea product. From these method has results:

1. Based on theBusinessModelCanvas(BMC)analysis, two business models are being recommended for marketing strategies for mangosteen peel nano tea. There are Business to Business (B2B) and Business to Customer (B2C). The B2B business model of mangosteen peel nano tea can be conducted in licensing and royalty activities agreement. While the $\mathrm{B} 2 \mathrm{C}$ business model can be conducted through direct sales of nano tea product based on mangosteen peel to the consumers.

2. From CI analysis, there are two new success factors that can be used to increase the competitiveness of the value of mangosteen peel nano tea. These success factors are the production method of product and also the form of the product (nano size powder).

3. From the market element analysis shows the mangosteen peel nano tea product will be focused on West Java market with a market size is about $72.903,6$ tons a year. The productivity level of nano tea product based on mangosteen peel is about $300 \mathrm{~kg} /$ day or amount $35.904 \mathrm{Kg} /$ years. From this analysis shows the market share of the nano tea product based on mangosteen peel in West Java is about $0,05 \%$ with the segmentation for all people in west java with age 20-60 years who are concerned about healthy

\section{Recommendations}

This research focused on three strategy marketing analysis to define the market opportunities of nano tea based on mangosteen peel. This analysis provide some recommendation in order to establish the new business based on this product. However, this strategy marketing analysis is not enough, many areas can be analysed to support on creating new business based on new product development. Analysis for investment study and study of attractiveness of this product can be one of the alternative in the future research. How the supply chain strategy and how the linkage between upstream and downstream of the supply chain can be conducted to establish new product development is the other thing that can be used in future research materials.

\section{REFERENCES}

[BPS] Badan Pusat Statistik. 2017. Statistik Tanaman Buah-Buahan dan Sayuran Tahunan Indonesia. Jakarta: Badan Pusat Statistik.

Cobb P. 2003. Competitive intelligence through data mining. Journal of Competitive intelligence and management 81.

Creswell JW. 2003. RESEARCH DESIGN Qualitative, Quantitative. and Mixed Methods Approaches SECOND EDITION. California: Sage Publications.

Directorate General of Estate Crops . 2017. Produksi Teh di Indonesia. Jakarta: Directorate General of Estate Crops, Ministry of Agriculture.

Farris et al. 2010. Marketing Metrics: The Definitive Guide to Measuring Marketing Performance. Upper Saddle River, New Jersey: Pearson Education, Inc.

Kartajaya H.2005. Seri 9 Elemen Marketing: Hermawan Kartajaya on positioning. Jakarta: Mizan.

Kartajaya H. 2007. Seri 9 Elemen Marketing: Hermawan Kartajaya on Differentiation. Jakarta: Mizan.

Lako J. Trenerry VC. Wahlqvist M, Wattanapenpaiboon N. 2007. Phytochemical flavonols, carotenoids and teh oxidants properties of wide selection of fijian fruit, vegetables and other readily available foods.FoodChemistry101(4):1727-1741.https:// doi.org/10.1016/j.foodchem.2006.01.031.

LeidckerJK. 1984. Identifying and using critical Success factors. Long Range Planning 17(1): 23-32. https://doi.org/10.1016/0024-6301(84)90163-8.

Middleton V, Fyall A, Morgan M, Ranchhod A. 2013. Marketing in Travel and Tourism. Burlington, Routledge.

Ningsih N, Yasni S., Yuliani S. 2017. Sintesis Nanopartikel ekstrak kulit manggis merah dan kajian sifat fungsional produk enkapsulasinya. Jurnal Teknologi dan Industri Pangan 28(1): 27 35. https://doi.org/10.6066/jtip.2017.28.1.27.

Nurkamari P. 1979. Pemanfaatan Kulit Buah Manggis sebagai Bahan Pembuat Gel. Jakarta: Departemen Perindustrian.

Osterwalder A, Pigneur Y. 2010. Business model generation: A handbook for visionaries, game changers, and challengers. New Jersey: John Wiley \& Sons Inc.

Palakawong C. 2010. Antioxi-dant and antimicrobial activities of crude extracts from mangosteen (Garcinia mangostana L.) parts and some essential oils. International Food Research 
Journal 17: 583-589.

Pride W et al. 2018. Marketing Principles. Australia: Cengage: 3rd Asia-Pacific ed.

Putra, Sitiatava R. 2011. Manggis Pembasmi Kanker. Yogyakarta: DIVA Press.

Rifai G. 2011. Guidebook Workshop Competitors Intelligence: Finding, Analyzing, and Using Information about Competitor to Gain Competitive Advantage. Bandung: MarkPlus
Inc.

Sugiyono. 2013. Metode Penelitian Pendidikan Pendekatan Kuantitatif, Kualitatif, dan R\&D. Bandung: Alfabeta.

Xia BS, Gong P. 2012. Review business intelligence through data analysis. Benchmarking: An International Journal 21(2): 300-311. https:// doi.org/10.1108/BIJ-08-2012-0050. 